\title{
Blastomere Content of Cultured/Frozen Bovine Demiembryos
}

\author{
By M. Schmidt, S. D. Smith, B. Avery, B. Purwantara and T. Greve \\ Department of Clinical Studies, Reproduction, Royal Veterinary and Agricultural University, Frederiksberg, \\ Denmark.
}

\begin{abstract}
Schmidt, M., S. D. Smith, B. Avery, B. Purwantara and T. Greve: Blastomere content of cultured frozen bovine demiembryos. Acta vet. scand. 1992, 33, 363-367. - The purpose of the study was to evaluate whether a period of co-culture with bovine oviduct epithelial cells (BOEC) could improve the tolerance of bisected bovine embryos to freezing and thawing. Day 6 embryos were bisected and the resulting demiembryos were stained with Hoechst 33342 and cell counts were made by counting intact blastomere nuclei. Of these, 11 were stained as freshly manufactured demiembryos, 25 after co-culture for $24 \mathrm{~h}$ with BOEC and 37 stained after $24 \mathrm{~h}$ co-culture and freezing and thawing. The staining revealed, that there was no significant difference in cell count of demiembryos that were stained immediately after bisection, compared to those, that were co-cultured for a $24 \mathrm{~h}$ period. Also, the cocultured/frozen/thawed demiembryos had a significant decrease in cell numbers compared to the non-frozen demiembryos. We conclude, that a $24 \mathrm{~h}$ period of co-culture with BOEC does not result in appreciable cellular proliferation in demiembryos and therefore instead of improving the survival of frozen/thawed demiembryos by giving them opportunity to multiply their cell number and thus make them more resistant to cell damage, rather compromised the viability of cryopreserved demiembryos.
\end{abstract}

co-culture; freezing; cellnumber; staining.

\section{Introduction}

Transfer of bovine demiembryos, may yield a lower pregnancy rate than the transfer of intact embryos possibly due to the reduction in cell numbers (Willadsen 1982, Lehn-Jensen \& Willadsen 1983, McEvoy \& Sreenan 1990, Schwidersky et al. 1990, Holm et al. 1991, Schmidt et al. 1992). Besides reducing the blastomeres to half the number, the micromanipulation process itself results in loss of cells from the demiembryos (Chesne et al. 1987, Niebart et al. 1988, Skrzyszowska \& Smorag 1989). However, a holding period of $1 / 2-1$ hour following bisection is sufficient to allow repair of the actual damage inflicted by microsurgery (Albihn et al. 1990).
Freezing of demiembryos results in lower pregnancy rate and viability than freezing of intact embryos (Picard et al. 1985, Lehn-Jensen, 1986 Picard et al. 1988, Seike et al. 1991, Schmidt et al. 1992) possibly due to a further reduction in the blastomere number, (for rewiev, see Niemann, 1991.)

The aim of the present study was to examine whether co-culture of demiembryos on bovine oviduct epithelial cells (BOEC) for 24 $\mathrm{h}$ prior to freezing would give the demiembryos opportunity to increase the number of blastomeres and in this way make them more competent to survive freezing. 


\section{Materials and Methods}

Superovulation and embryo collection

Ten days after estrus dairy cows and heifers were treated with $35 \mathrm{mg}$ FSH (Folltropin Vet $^{R}$, Coopers Animal Health Ltd) in a decreasing dosage regimen for 4 days. Seventy-two $\mathrm{h}$ after the initial FSH treatment a single injection of prostaglandin (Estrumat Vet $^{R}$, Coopers Animal Health Ltd) was administered to induce luteal regression. Artificial insemination was performed 12 and $24 \mathrm{~h}$ after the onset of standing heat. Flushings were performed 6 days after heat with Dulbeccos PBS containing $36 \mathrm{mg} / \mathrm{l}$ pyruvate, $1000 \mathrm{mg} / \mathrm{l}$ glucose, $25 \mathrm{mg} / \mathrm{l} \mathrm{kanamycinesul-}$ phate and $0.5 \%$ heat inactivated fetal calf serum (FCS).

The embryos were washed and stored in the PBS with $10 \%$ FCS until morphological evaluation and onset of bisection.

\section{Bisection of embryos}

The embryos were bisected within a droplet of PBS containing $20 \%$ FCS under a compound microscope using 2 Leitz micromanipulators. While fixed with a holding pipette, embryos were bisected symmetrically with an opthalmic blade (Beaver,USA). The bisection was done inside or outside the zona and with a transfer pipette the one half of the embryo was returned to the original zona, and the other half to a surrogate zona from the same donor or from another donor flushed at the same day.

A total of 93 demiembryos were used in this study.

\section{Culture of demiembryos before freezing}

Bovine oviduct epithelial cells (BOEC) were prepared from slaughterhouse oviducts, as previously described (Schmidt et al. 1990).

The demiembryos were cultured for $24 \mathrm{~h}$ on a confluent monolayer of BOEC in TCM-199 with Earles salts supplemented with $10 \%$ FCS, $2 \mathrm{mM}$ glutamine, penicilline 200 i.u. $/ \mathrm{ml}$, streptomycin $200 \mu \mathrm{g} / \mathrm{ml}$, fungizone $2.5 \mu \mathrm{g} / \mathrm{ml}$ in $5 \% \mathrm{CO}_{2}$ in humified air at $38.5^{\circ} \mathrm{C}$.

\section{Freezing/thawing of demiembryos}

After the culture period, some of the demiembryos, which by a morphological evalution were judged as viable, were frozen. The freezing medium consisted of $10 \%$ sterile glycerol in Dulbeccos PBS supplemented with $10 \%$ FCS. The demiembryos were equilibrated in the freezing medium for $20 \mathrm{~min}$ at room temperature $\left(21^{\circ} \mathrm{C}\right)$, aspirated in 0.25 $\mathrm{ml}$ straws, which contained 1 demiembryo and were placed at $-6^{\circ} \mathrm{C}$ for $10 \mathrm{~min}$ in the chamber of an automatic alcohol embryo freezer (Julabo HC, FP 50). After seeding, the straws were cooled to $-35^{\circ} \mathrm{C}$ at a cooling rate of $-0.4^{\circ} \mathrm{C}$ per minute after which they were plunged into liquid nitrogen and stored at $-196^{\circ} \mathrm{C}$.

Thawing was done 1-6 months later in air for $1 \mathrm{~min}$ at room temperature. The demiembryos were placed in 1.0 M sucrose for 6-8 min. and subsequently transferred to PBS with $10 \%$ FCS and evaluated for stage of development and embryo quality grade.

A few demiembryos $(n=6)$ were lost under the processes and some of the embryos were obviously degenerated at the end of the culture or freezing period, (about 25\%) and were not included in this study.

\section{Staining}

Demiembryos, which by a morphological evaluation were considered viable $(n=73)$, were stained to vizualize the blastomeres; immediately after bisection $(\mathrm{n}=11)$, after coculture $(n=25)$ or after co-culture/freezing/thawing $(n=37)$. Embryos were placed into Hoechst 33342 (Sigma) at $20 \mu \mathrm{g} / \mathrm{ml}$ for $5-10$ $\min$ at $37^{\circ} \mathrm{C}$. They were washed once and 
mounted on a glass slide under a coverslip supported by a ring of vaseline, and then observed under a Zeiss CM 35 flourescence microscope at $400 \mathrm{X}$. Only unlysed nuclei from intact blastomeres were counted.

\section{Statistical Analysis}

The data were statistically analyzed using the Chi-square test (SAS Institute, 1988) with a level of significance of $p<0.05$.

\section{Results}

\section{Culture prior to freezing}

Staining of 36 non-frozen demiembryos made it possible to asses the number of blastomeres before and after co-culture. Table 1 shows that the major proportion of the demiembryos contained 20-50 blastomeres. Apart from an apparent reduction in the proportion of demiembryos containing more than 50 blastomeres after the $24 \mathrm{~h}$ culture period ( $27 \%$ before versus $20 \%$ after), no significant differences were found.

\section{Freezing/thawing}

The influence of freezing/thawing on the survival of the demi-embryos was evaluated by staining of 37 cultured-frozen-thawed demiembryos (Table 1). As before freezing the largest group still had 20-50 blastomeres. However, non of the demiembryos contained more than 50 blastomeres after freezingthawing $(\mathrm{p}<0.01)$.

\section{Discussion}

The objective of the present study was to make the demiembryos more resistant to the freezing damage by co-culture on BOEC for a number of $h$ prior to freezing, giving them an opportunity to regenerate and, since the restoring of the prebisection morphology occurs in $30 \mathrm{~min}$ (Albihn et al. 1990), to increase the number of blastomeres during the culture period.

The study showed however, that co-culture for $24 \mathrm{~h}$ prior to freezing/thawing of demiembryos did not improve their viability assessed by the number of blastomeres. Most of the demiembryos contained 20-50 blastomeres, which is in agreement with Lehn-Jensen \& Willadsen (1983), who found that demiembryos contained 29-55 normal blastomeres before freezing. Niebart et al.(1988) found by staining half bovine embryos from young blastocysts, that the demiembryos contained $30-43$ cells and the bisection resulted in a loss of approximately $9 \%$.

Culture prior to freezing of zonafree demiembryos was attemted by Chesne et al.(1987) who concluded that a short 4-6 h culture period before freezing was beneficial. On the other hand, Armas et al. (1992) found degeneration and dispersion of the cells in demiembryos already after $6 \mathrm{~h}$ culture, and after $24 \mathrm{~h}$ culture, they found a pregnancy rate of $0 \%$. A similar reduction in viability was registred by Lucas-Hahn \& Niemann (1991)

Table 1: Distribution of fresh, co-cultured $(24 \mathrm{~h})$ and frozen-thawed demiembryos according to the number of blastomeres counted after staining with Hoechst 33342 (Sigma).

\begin{tabular}{lcccccc}
\hline $\begin{array}{l}\text { Demi- } \\
\text { embryos }\end{array}$ & $\begin{array}{c}\text { No. of } \\
\text { demi- } \\
\text { embryos }\end{array}$ & $<10$ & $10-20$ & $20-50$ & $50-100$ & $>100$ \\
\cline { 3 - 7 } & 11 & 1 & 3 & 5 & 2 & 1 \\
\hline Fresh & 25 & 7 & 11 & 12 & 2 & 3 \\
$\begin{array}{l}\text { Co-cultured } \\
\text { Co-cultured }\end{array}$ & 37 & & & & & \\
and frozen & & & & & & \\
\hline
\end{tabular}


who cultured the demi-embryos 1-3 $\mathrm{h}$ before the freezing process, and found a survival rate of $71 \%$ immediately after thawing. However, after $24 \mathrm{~h}$ culture the survival rate was reduced to $28 \%$ and the authors suggested, that new freezing procedures or new coculture systems (Lucas-Hahn 1992) were needed to overcome the enormous sensitivity of demiembryos to freezing and thawing.

Finally Schmidt et al.(1992) found that $67 \%$ of 243 fresh demiembryos developed in $24 \mathrm{~h}$ culture while approximately $90 \%$ of intact embryos developed. Only $28 \%$ of 32 cultured/frozen/thawed demiembryos survived $24 \mathrm{~h}$ co-culture compared with $64 \%$ of intact embryos.

In Table 1 it is seen, that the number of demiembryos containing many blastomeres was slightly lower after culture and significantly decreased after freezing/thawing. A few of the demiembryos $(n=4)$ contained more than 100 cells, which could indicate an uneven bisection. But since the size of the 2 halfs from each embryo were not registered, this study did not allow an accurate assessment of its influence upon the subsequent cellnumber of the demiembryo.

Thus, the present study showed that co-culture prior to freezing instead of improving the survival of frozen demiembryos by giving them opportunity to multiply their cell number and thus make them more resistant to freezing damage, rather reduced their cell number. The freezing/ thawing process made another decrease in the number of cells, and thus further compromising the viability of cryopreserved demi-embryos.

\section{Acknowledgement}

A part of this work was supported by the Animal Biotechnology Research Center, The Royal Veterinary and Agricultural University, Copenhagen.

\section{References}

Albihn A, Rodriguez-Martinez H, Gustafson $H$ : Morphology of day 7 bovine demi-embryos during in vitro reorganization. Acta Anat. 1990, 138, 42-49.

Armas de R, Solano R, Bernel A, Gonzalez F: Factors affecting in vitro and in vivo viability of bisected cattle embryos. Theriogenology 1992, 37, 199.

Chesne P, Heyman $Y$, Chupin D, Procureur $R$, Menezo Y: Freezing of cattle demiembryos: Influence of a period of culture betwween splitting and freezing on survival. Theriogenology 1987, 27, 218.

Holm P, Greve T, Bak A, Schmidt M: Bisection of bovine morulae and blastocysts from superovulated danish dairy cows. Acta vet. scand.1991, 32, 47-53.

Lehn-Jensen $H$ \& Willadsen S: Deep-freezing of cow 'half' and 'quarter' embryos. Theriogenology $1983,19,49-54$.

Lehn-Jensen $H$ : Cryopreservation of bovine embryos. Diss. The Royal Veterinary and Agricultural University, Copenhagen 1986, 183 pp

Lucas-Hahn $A \&$ \& Niemann $H$ : In vitro survival of fresh and frozen/thawed bovine demi-embryos. Theriogenology 1991, 36, 619-627.

Lucas-Hahn A: Status of cryopreserving micromanipulated bovine embryos.Embryo Transfer Newsletter, 1992, 10, 18-23.

McEvoy $T G$ \& Sreenan JM: Effect of embryo quality and stage of development on the survival of zona pellucida-free cattle demi-embryos. Theriogenology 1990, 33, 1245-1253.

Niebart M, Sripongpun S, Cedden F, Mechekour F, Guienne le B, Thibier M: Histological study of bovine intact and demi-embryos. Theriogenology 1988, 29, 283.

Niemann $H$ : Cryopreservation of ova and embryos from livestock: Current status and research needs. Theriogenology 1991, 35, 109-124.

Picard L, King A, Betteridge $K \mathrm{~J}$ : Production of sexed calves from frozen/thawed embryos. Vet. Rec. 1985, 117, 603-608.

Picard L, Schneider U, Betteridge KJ, King WA: Effect of the zona pellucida, agar embedding and culture on the survival of micro-manipulated bovine embryos after freezing and thawing. J. In Vitro Fertil. Embryo Transf. 1988, 5, 268274.

Schmidt M, Avery B, Purwantara B, Roschlau K, Greve $T$ : In vitro culture of bovine demi- 
embryos on bovine oviduct ephithelial feeder cells. Reprod.Dom.Anim. 1990, 25, 167-172.

Schmidt M, Smith $S D$, Avery B, Purwantara B, Greve T: Coculture of bovine demiembryos prior to freezing. Acta vet. scand.1992, 33, 237243.

Schwidersky H, Seifert F, Genz S: Bovine embryo splitting - International trend and own results. Arch.Tierz, Berlin 1990, 33, 139-148.

Seike N, Sakai M, Kanagawa H: Development of frozen/thawed demiembryos and production of identical twin calves of different age. J.vet.med.Sci.1991, 53, 37-42.

Skrzyszowska M, Smorag Z: Cell loss in bisected mouse, sheep and cow embryos. Theriogenolo 1989, 32, 115-122.

Willadsen S: Micromanipulation of embryos of the large domestic species. Diss. The Royal Veterinay and Agricultural University, Copenhagen (1982), 26 pp.

SAS Institute Inc.: SAS/STAT Guide for Personal Computers, Version 6.03. Cary, NC, USA. 1988.

\section{Sammendrag \\ Blastomer antal i dyrkede/nedfrosne bovine demien- bryoner.}

Tidligere fors $\emptyset \mathrm{g}$ har vist, at dyrkning med BOEC ikke forbedrer frysbarheden af halve kvægembryoner, demiembryoner. Hensigten med denne dyrkningsmetode skulle være, at give demiembryonerne tid til at restituere sig efter mikromanipulationsprocessen og give dem lejlighed til yderligere at forøge celleantallet, således at de bliver mere velegnede til at overleve frysningen. Formålet med nærværende fors $\emptyset \mathrm{g}$ var at få et indtryk af celleantallet i dyrkede og frosne demiembryoner ved at farve med Hoecht 33342 (Sigma). Af 73 farvede og bedømte demiembryoner var de 11 friske, de 25 var dyrkede i 24 timer med bovine ovidukt epithel celler (BOEC), og de 37 var dyrkede, frosne og optøede.

Resultaterne var, at der efter en $24 \mathrm{t}$ dyrkningsperiode skete et mindre, ikke signifikant fald $i$ antallet af demiembryoner med normalt antal blastomerer, men efter frysning og optøning viste der sig at være significant færre demiembryoner end før frysningen med det normale antal celler. Det fremgår således, at det ikke var muligt at forøge antallet af blastomerer i demiembryoner ved at dyrke med BOEC, og at fryseprocessen reducerede celle-antallet yderligere.

(Received June 19, 1992; accepted August 26, 1992).

Reprints may be requested from: M. Schmidt, Department of Clinical studies, Reproduction, Royal

Veterinary and Agricultural University, 13 Bülowsvej, DK-1870 Frederiksberg C, Denmark. 